\title{
Influence of environmental factors on the characteristics of macrobenthic communities in soft bottoms around coral reefs of Larak Island (Persian Gulf)
}

\section{Influence des facteurs environnementaux sur les caractéristiques des communautés macrobenthiques des fonds meubles autour des récifs coralliens de l'île de Larak (golfe Persique) (traduit par la rédaction)}

\author{
Shima Tavanayan ${ }^{1}$, Sana Sharifian ${ }^{1,{ }^{*}}$, Ehsan Kamrani ${ }^{2}$, Mohammad \\ Seddiq Mortazavi ${ }^{3}$, Siamak Behzadi ${ }^{3}$ \\ 1 Department of Marine Biology, University of Hormozgan, Bandar Abbas, Iran \\ sharifian.phd@hormozgan.ac.ir \\ 2 Fishery Department, University of Hormozgan, Bandar Abbas, Iran \\ ${ }^{3}$ Persian Gulf and Oman Sea Ecological Research Institute, Iranian Fisheries Sciences Research \\ Institute, Agricultural Research Education and Extension Organization (AREEO), Bandar Abbas, \\ Hormozgan, Iran
}

\begin{abstract}
The effective conservation of coastal ecosystems including soft bottoms around coral reefs of Larak Island, Persian Gulf is requiring basis data on community structure at different relevant spatial scales. In this regard, the diversity and the abundance of the macrobenthic communities in soft bottoms around coral reefs of this area were described in relation to different environmental factors. A seasonal sampling was conducted at two stations located in the east and west of Larak Island, respectively, during 4 seasons, from spring to winter 2012. A total of 20 species which belong to 20 genera and 14 families were identified. The macrobenthic density showed significant differences among seasons. The Shannon-Wiener index ranged from 2.07 to 2.89 indicating a moderate diversity in both stations. The maximum diversity of macrobenthic organisms was observed during spring. A non-metric multidimensional scaling (NMDS) analysis showed a large overlap in the macrobenthic community structure between the two stations. A principal component analysis (PCA) analysis indicated that the main environmental factors controlling macrobenthic density were phosphate, dissolved oxygen and total organic matter (TOM). Our results indicated that coral macrobenthic communities in Larak Island were characterized by low density and uniform distribution of species.
\end{abstract}

Keywords - macrobenthic communities, benthos, density, diversity, environmental variables, coral reef 
Résumé - Une conservation efficace des écosystèmes côtiers, y compris des fonds meubles autour des récifs coralliens de l'île de Larak, dans le golfe Persique, nécessite des données de base sur la structure des communautés à différentes échelles spatiales pertinentes. À cet égard, la diversité et l'abondance des communautés macrobenthiques dans les fonds meubles autour des récifs coralliens de cette zone ont été décrites en relation avec différents facteurs environnementaux. Un échantillonnage saisonnier a été effectué au niveau de deux stations situées respectivement à l'est et à l'ouest de l'île de Larak pendant 4 saisons, du printemps à l'hiver 2012. Au total, 20 espèces appartenant à 20 genres et 14 familles ont été identifiées. La densité macrobenthique a montré des différences significatives entre les saisons. L'indice de Shannon-Wiener a varié entre 2,07 et 2,89, indiquant une diversité modérée dans les deux stations. La diversité maximale des organismes macrobenthiques a été observée au printemps. Une analyse de positionnement multidimensionnel non métrique (NMDS) a montré un grand chevauchement dans la structure de la communauté macrobenthique entre les deux stations. Une analyse en composantes principales (ACP) a indiqué que les principaux facteurs environnementaux contrôlant la densité macrobenthique étaient le phosphate, l'oxygène dissous et la matière organique totale (MOT). Nos résultats ont indiqué que les communautés macrobenthiques coralliennes de l'île Larak étaient caractérisées par une faible densité et une répartition uniforme des espèces.

Mots clés -communautés macrobenthiques, benthos, densité, diversité, variables environnementales, récif corallien

\section{Introduction}

Coral ecosystems are among the most productive marine ecosystems worldwide. They support diverse communities of marine organisms and offer substantial commercial, recreational and cultural values to society (Fukunaga et al., 2017). Benthic communities of coral ecosystems can vary with depth, from a community dominated by photosynthetic organisms in shallower depths to communities composed of obligate heterotrophs at greater depths (Kahng et al., 2014). Nowadays, increased attention has been paid on coral habitats because of their increasing exposure to global and local disturbances which threaten their biodiversity (Lindfield et al., 2016).
Major threats to these ecosystems include climate change (e.g. increase in thermal stress), increase in sedimentation with reduced photosynthetically active radiation, strong wave action, nutrient enrichment, overexploitation of marine resources, and invasive species (Pyle et al., 2016), which can have dramatic consequences on world's reefs (Jackson, 2010) and on the composition and structure of benthic communities (Fukunaga et al., 2017). In this context of increasing human activities, there is a need and a demand to identify the responses of macrobenthic communities to environmental changes. Data on community structure (species composition and abundance) at different relevant spatial scales can provide crucial information for the 
effective management and the conservation of these coastal marine ecosystems (Casas Guell et al., 2015).

Numerous research studies have focused on patterns of macrobenthic assemblages in relation to environmental factors including sedimentary and hydrological variables on intertidal and shallow sublittoral soft bottoms in temperate systems (Veiga et al., 2016; Veiga et al., 2017) or in tropical ones (Alsaffar et al., 2019). Some studies have already examined the biodiversity and structure of marine macrobenthic communities in the Persian Gulf and Oman Sea including soft-bottom communities from subtropical estuaries of the Northern coasts of Oman Sea (Taherizadeh \& Sharifinia, 2015). These studies suggested that temporal changes in the macrobenthic composition were related to physicochemical parameters. Similarly, Moradi et al. (2014) showed that the spatial and temporal distributions of scleractinian coral communities could be affected by environmental variables. The purpose of the present study is to describe, for the first time, the spatial and temporal structure of macrobenthic communities in soft-bottom around coral reefs of Larak Island from Persian Gulf (Iran) and the influence of environmental variables on these community structure.

\section{Materials and methods}

\subsection{Studied sites}

The structure of corals in the waters around Larak Island was determined using existing distribution maps of corals indicating geographical coordi- nates of corals as well as field diving observations for depths $<5 \mathrm{~m}$ and the Manta tow survey (with towing a snorkel diver behind a small boat along the upper reef slope to make direct observation of corals in a broad scale) and scuba diving methods for deeper depths. Subsequently, two stations were selected: station 1 located in the east of Larak Island $\left(26^{\circ} 84^{\prime} \mathrm{N}\right.$ $\left.56^{\circ} 39^{\prime} \mathrm{E}\right)$ and station 2 located in the west of Larak Island in front of the Larak's residential area, $\left(26^{\circ} 87^{\prime} \mathrm{N}-\right.$ $56^{\circ} 33^{\prime}$ E) (Fig. 1).

\subsection{Sampling procedure and measurements}

At each station, the sampling of corals was performed through diving and the usage of $50 \times 50 \mathrm{~cm}$ quadrate. A "Petersen" grab with an opening of $0.4 \mathrm{~m}^{2}$ was used for sediment sampling. At each station, three grab samples were collected at each season (from spring to winter 2012). Immediately after collection, sediment samples were sieved on a $0.5 \mathrm{~mm}$ mesh sieve and the macrobenthic organisms were preserved with diluted alcohol $(70 \%)$ before being identified to the lowest possible taxonomic level, in general the species level, counted and weighed with an accuracy of $0.001 \mathrm{~g}$. The following references were used for species identification: Tagliapietra \& Sigovini (2010), and Castelli et al. (2004). Physical and chemical properties of water (i.e. temperature, salinity, oxygen and turbidity) were measured by a multiparametric CTD SBE25 probe in near-bottom waters (Ostrovskii \& Zatsepin, 2011). 


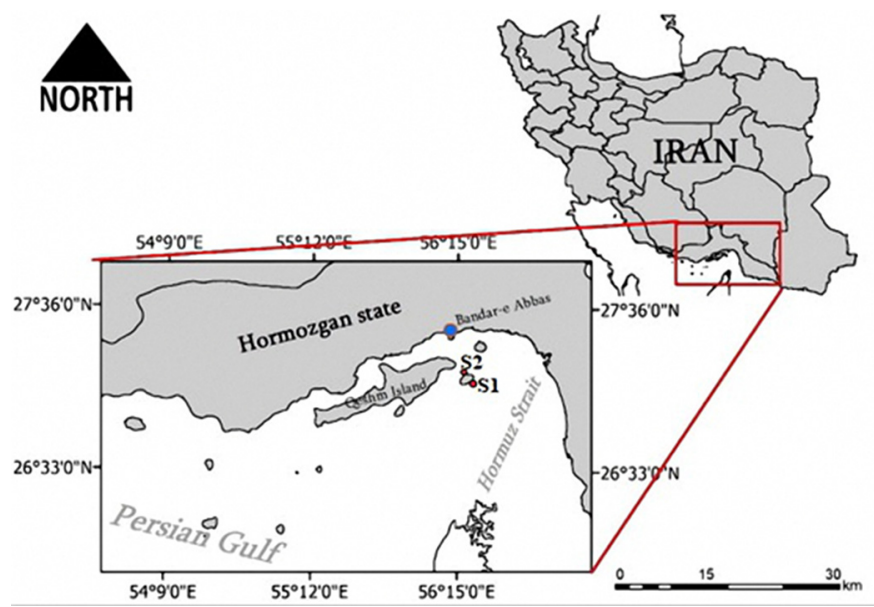

Fig. 1. Sampling locations showing station 1 (S1) in the east of Larak Island and station 2 (S2) in the west of Larak Island, Persian Gulf.

Fig. 1. Lieux d'échantillonnage montrant la station 1 (S1) à l'est de l'île Larak et la station 2 (S2) à l'ouest de l'île Larak, golfe Persique.

Species number and abundance were expressed as the number of species and the number of individuals per $\mathrm{m}^{2}$ respectively. Particle size distribution of sediment was analyzed by sieving dry sediment through a stack of Wentworth grade sieves according to the technique described by Buchanan (1984). The sediment was characterized by the percentage of fine particles $<63 \mu \mathrm{m}$, the percentage of particles between $500 \mu \mathrm{m}$ and $2 \mathrm{~mm}$, and the percentage of particles $>2 \mathrm{~mm}$. The total organic matter (TOM) was determined using the loss on ignition method at $525^{\circ} \mathrm{C}$ for $4 \mathrm{~h}$ (Caeiro et al., 2005). The measurements of nitrate, nitrite, silicate, and phosphate from near bottom waters were performed following international standards (APHA, 2002) using a spectrophotometer according to the recommendations of the manufacturer's manual book.

\subsection{Data analyses}

The species diversity was calculated using the Shannon-Wiener diversity index (H'; Shannon, 1948), the Simpson index of diversity (D; Simpson, 1949) and the species richness (M; Margalef 1958). The evenness was estimated by Pielou's evenness index (J'; Pielou, 1966). These indices were used to evaluate the ecological quality status. Shannon-Wiener diversity index $\left(H^{\prime}\right)$, Simpson index of diversity (D), species richness (Margalef: M) and Pielou's evenness index $(J)$ were tested for normality using the Kolmogorov-Smirnov (Lilliefors) (D) test and showed normality. We have also tested homogeneity of variance for four indices (Levene's test). Subsequently, they were subjected to parametric methods. We used 2-way analyses of variance (ANOVAs) to assess the 
effects of both seasons and stations on the abundance of macrobenthos and diversity indices. The physico-chemical variables (mean \pm standard deviation) were calculated for each sampling site during the sampling period. The Kolmogorov-Smirnov test was used to assess the normality of data distribution. The physico-chemical variables and total abundance of macrobenthos showed normal distributions $(P>0.05)$, subsequently parametric tests were used. The physico-chemical variables were compared between two stations and among four seasons through 2-way ANOVAs. The correlation between the physico-chemical variables and total abundance of macrobenthos was tested through a Pearson's correlation.

The structure of the macrobenthic communities was analysed by a cluster analysis and a non-metric multidimensional scaling (NMDS) based on BrayCurtis similarities on the relative abundances of the macrobenthic species. Similarity analyses (ANOSIM) were used for the detection of any significant differences in community structure between the two stations. A SIMPER (similarity of percentages) procedure was used to examine the contribution of taxa to the similarities (or dissimilarities) among seasons. The statistical package PRIMER version 5.0 was used for these analyses.

The association between the densities of the dominant species (Including Cirratulus cirratus, Solen dactylus, and Hediste diversicolor) with environmental variables (including salinity, dissolved oxygen, phosphate, silicate, turbidity, nitrate, nitrite, and $\mathrm{pH}$ ) and sedimentary parameters (including TOM, silt, clay and sand) were investi- gated by a principal component analysis $(P C A)$. For this purpose, environmental variables were standardized and log-transformed before running PCA. In PCA, the KMO and Bartlett's tests were used for suitability and validity level of data (Zhou et al., 2006). In order to identify hidden component and variables, the rotation method was used.

\section{Results}

\subsection{Main species of coral reef}

Manta tow survey showed that the main scleratinian corals present in the study area included the families Poritidae (Porites compressa), Faviidae (Dipsastraea matthaii, Favites pentagona, Cyphastrea microphthalma, Platygyra daedalea, Leptastrea transversa) and Siderastreidae (Siderastrea savignyana, Coscinaraea columna). The highest coverage rate was observed for Porites compressa and Leptastrea transversa. Conversely, stone corals Cyphastrea microphthalma and Coscinaraea columna had the lowest coverage rate.

\subsection{Species composition on soft bottom around coral reefs}

Based on morphological characteristics, a total of 20 species (including 6 Mollusca, 6 Arthropoda, 6 Annelida, and 2 Echinodermata) were identified (Tab. 1). They belong to 14 families and 20 genera. Additionally, one ostracod was identified at the genus level. The total abundances of the different species have also shown in Table 1. The minimum of total abundance was 
observed for Metaprotella macoranicus and Glyphocuma dentatum at station 1 and for Metacytheropteron at station 2. We observed the maximum of total abundance for Murex echinodes and Aphelochaeta monilaris at station 1 and Solen dactylus at station 2 (Tab. 1). The total abundance of Murex echinodes, Metacytheropteron, Hediste diversicolor, and Aphelochaeta monilaris showed significant differences between stations (2-way ANOVAs; $P<0.05)$. Moreover, the total abundance of Neverita didyma, Murex echinodes, Solen dactylus, Gnathia maxillaris, Carcinus maenas, Cirratulus cirratus, and Echinometra mathaei showed significant differences between four seasons (2-way ANOVAs; $\mathrm{P}<0.05)$ (Tab. 1).

Among the three dominant species, Cirratulus cirratus and Solen dactylus showed the significant differences in the total abundances between seasons (2-way ANOVAs; $d f=3 ; \quad F=7.91 ; P$ $<0.01$ for C. cirratus, $F=33.30$; $P$ $<0.01$ for $S$. dactylus) (Fig. 2). In contrast, the total abundances of Hediste diversicolor did not vary significantly with seasons (2-way ANOVAs; $P>0.05$ ) (Fig. 2). The species richness showed the highest and lowest numbers in spring at station 1 and in summer at station 2, respectively (Fig. 3). There was no significant difference in species richness between stations (2-way ANOVAs; $P>0.05)$, and among seasons (2-way ANOVAs; $P>0.05$ ).

\subsection{Physico-chemical parameters}

The environmental data obtained at each station during four seasons are given in Table 2. Temperature showed a significant difference among the four seasons (2-way ANOVAs; $F=7.42$, $\mathrm{P}<0.01)$ and significant differences between stations were detected depending on the season (2-way ANOVAs $\mathrm{F}=5.97 ; \mathrm{P}<0.01)$. Other parameters (except $\mathrm{pH}$ ) showed significant differences between different seasons $(P<0.05)$, stations $(P<0.05)$ and in terms of interaction $(P<0.05)$. The Pearson's correlation coefficients calculated between the physico-chemical parameters and the total abundance of macrobenthos showed that water temperature and salinity were the most significant factors influencing the total abundance $(\mathrm{N}=24 ; \mathrm{r}=0.55 ; \mathrm{P}$ $<0.05$ for temperature and $\mathrm{N}=24$; $r=0.57 ; P<0.01$ for salinity), while other parameters showed no significant correlation with total abundance of macrofauna.

The percentage of sediment fractions and organic matter contents for 2 stations during the four seasons are shown in Table 3. There was no significant difference in the percentage of sand particles, silt and clay between the two stations $(P>0.05)$, four seasons $(P>0.05)$ and in terms of interaction $(P>0.05)$ (Tab. 3), whereas TOM showed significant differences between stations (2-way ANOVAs; $F=32.67 ; P<0.01$ ), among seasons $(F=36.89, \quad P=0.00)$ and differences between stations depended on season (2-way ANOVAs; $F=4.43 ; \quad P<0.05)$. The results of the Pearson's correlation showed high and significant correlations between the total abundance of macrofauna and the TOM in sediments $(N=24 ; r=0.62 ; P<0.01)$ and the percentage of silt particles $(\mathrm{N}=24$; 


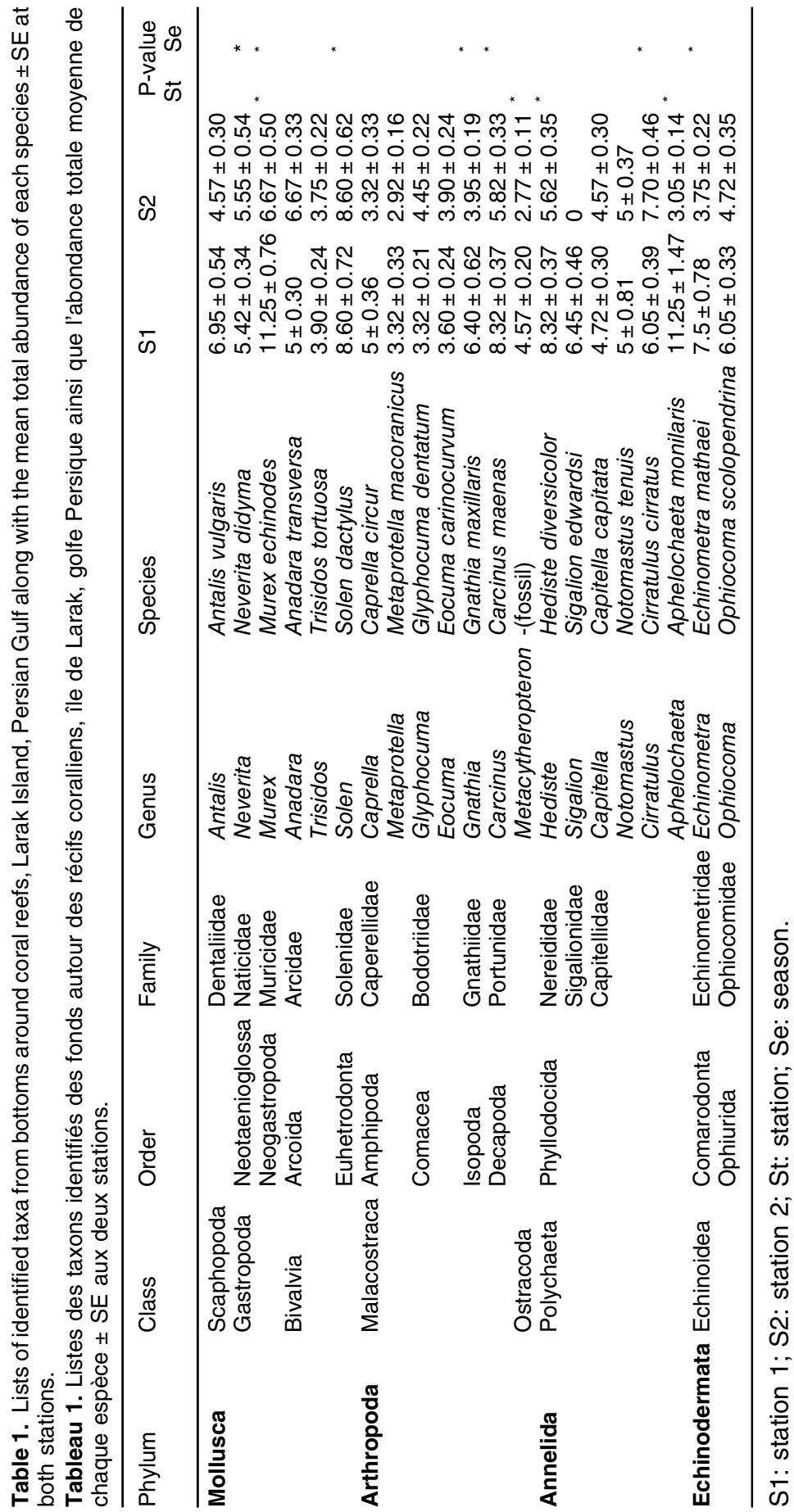




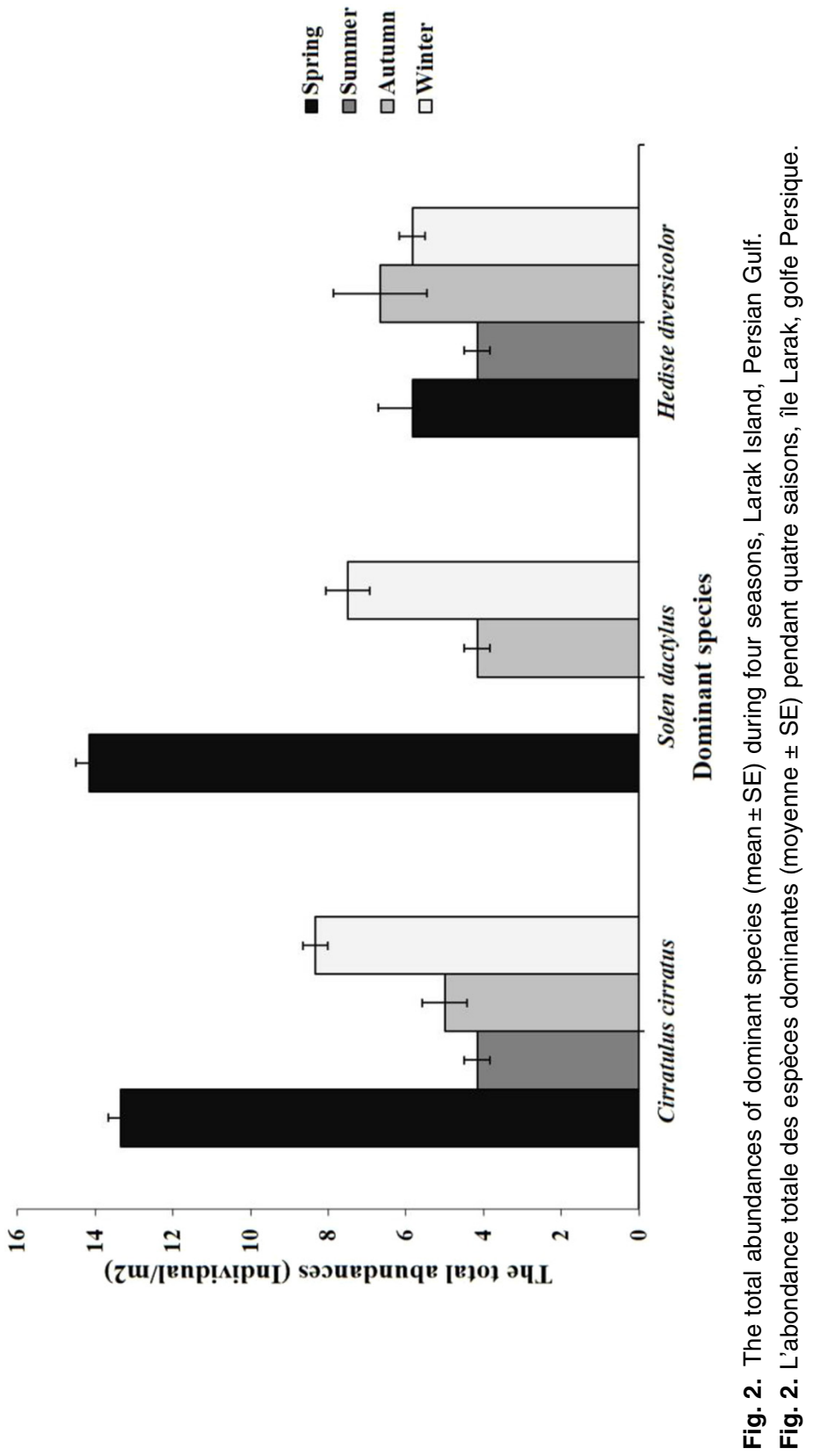




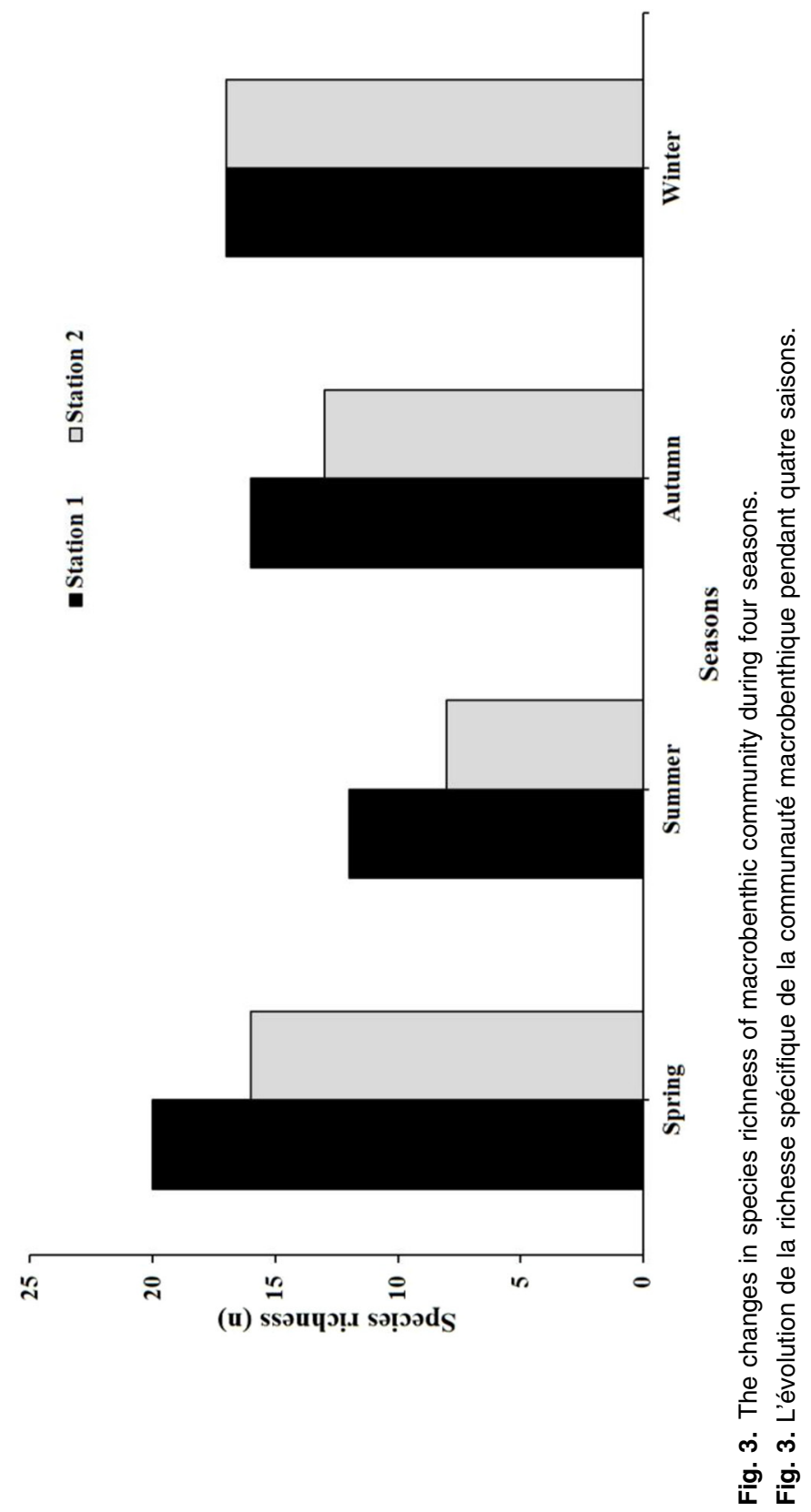




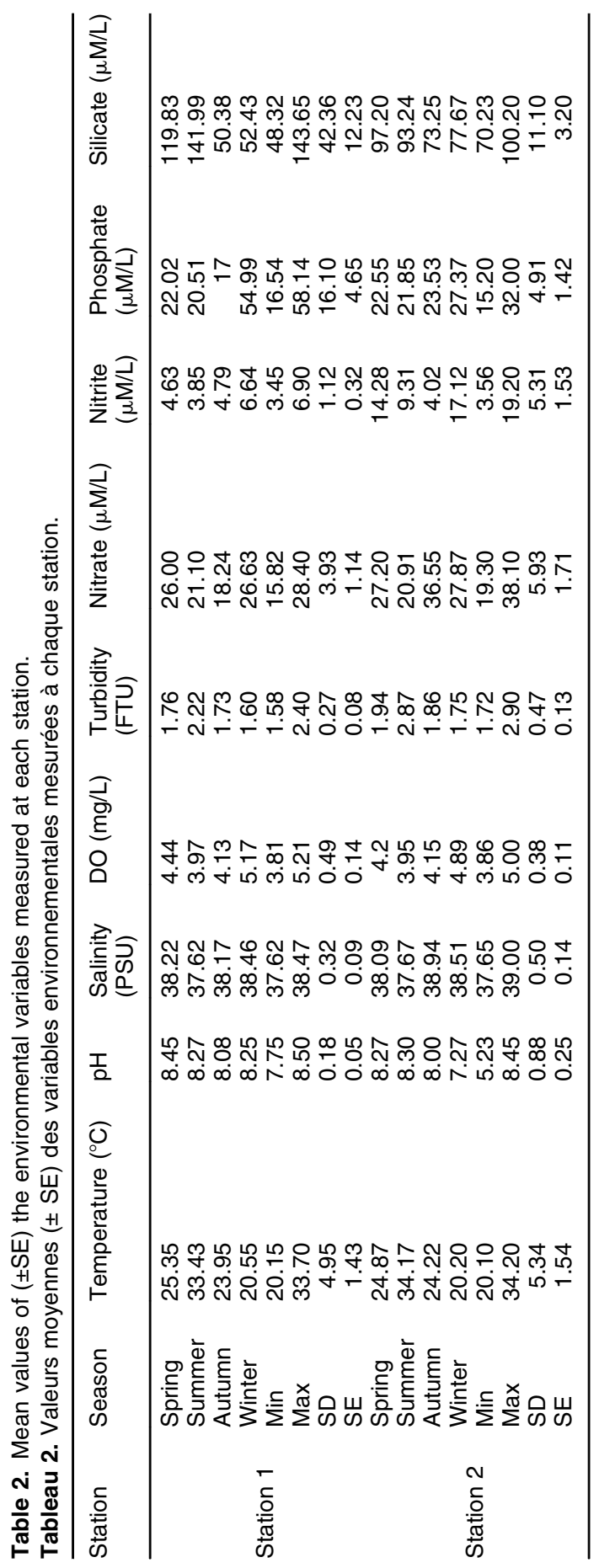


Table 3. Mean values $( \pm \mathrm{SE})$ of the sedimentary parameters measured at station 1 (S1) and 2 (S2) in Larak Island.

Tableau 3. Valeurs moyennes $( \pm S E$ ) des paramètres sédimentaires mesurés aux stations 1 (S1) et 2 (S2) de l'île Larak.

\begin{tabular}{|c|c|c|c|c|c|c|}
\hline Station & Season & & Sand (\%) & Silt (\%) & Clay (\%) & TOM (\%) \\
\hline \multirow{8}{*}{ S1 } & \multirow[b]{2}{*}{ Spring } & Mean & 92 & 5.33 & 8 & 0.65 \\
\hline & & SE & 0.58 & 0.33 & 0.58 & 0.03 \\
\hline & \multirow[b]{2}{*}{ Summer } & Mean & 91.83 & 4 & 8.17 & 0.33 \\
\hline & & SE & 0.44 & 0.58 & 0.44 & 0.02 \\
\hline & \multirow{3}{*}{ Autumn } & Mean & 92.67 & 5.50 & 7.33 & 0.51 \\
\hline & & SE & 0.88 & 1.04 & 0.88 & 0.01 \\
\hline & & Mean & 92.17 & 4.50 & 7.83 & 0.53 \\
\hline & Winter & SE & 1.30 & 1.04 & 1.30 & 0.02 \\
\hline \multirow{8}{*}{ S2 } & \multirow[b]{2}{*}{ Spring } & Mean & 90.33 & 4.33 & 9.67 & 0.65 \\
\hline & & SE & 0.88 & 0.88 & 0.88 & 0.03 \\
\hline & \multirow{2}{*}{ Summer } & Mean & 91.33 & 3.67 & 8.67 & 0.48 \\
\hline & & SE & 0.88 & 0.67 & 0.88 & 0.04 \\
\hline & \multirow[b]{2}{*}{ Autumn } & Mean & 92.33 & 2.33 & 7.67 & 0.65 \\
\hline & & SE & 1.45 & 0.33 & 1.45 & 0.02 \\
\hline & \multirow{2}{*}{ Winter } & Mean & 93.50 & 5.00 & 6.50 & 0.62 \\
\hline & & SE & 1.04 & 0.58 & 1.04 & 0.01 \\
\hline
\end{tabular}

Table 4. Formed groups based on a priori sampling design using data set of station 1 and 2, with indication each group similarity (\%) and the most representative species (\%) contributing for the similarity within each group, determined with SIMPER analysis.

Tableau 4. Groupes formés sur la base d'un plan d'échantillonnage a priori utilisant l'ensemble de données des stations 1 et 2 , avec indication de la similitude de chaque groupe (\%) et des espèces les plus représentatives (\%) contribuant à la similitude au sein de chaque groupe, déterminée par une analyse SIMPER.

\begin{tabular}{llc}
\hline Group & Main species & \% contribution \\
\hline Spring sampling period & Cirratulus cirratus & 21.38 \\
Average similarity 84\% & Solen dactylus & 30.76 \\
& Hediste diversicolor & 18.76 \\
Summer sampling period & Cirratulus cirratus & 6.55 \\
Average similarity 63.2\% & Solen dactylus & 8.72 \\
& Hediste diversicolor & 10.91 \\
Autumn sampling period & Cirratulus cirratus & 12.65 \\
Average similarity 82.76\% & Solen dactylus & 6.55 \\
& Hediste diversicolor & 15.05 \\
Winter sampling period & Cirratulus cirratus & 15.27 \\
Average similarity 88.24\% & Solen dactylus & 15.71 \\
& Hediste diversicolor & 16.58 \\
\hline
\end{tabular}

$r=0.45 ; P<0.05)$. Moreover, a positive and significant relationship was found between the total abundance of macrofauna and the proportion of sand and clay particles $(\mathrm{N}=24$; $r=0.99 ; P<0.01)$.

\subsection{Spatial and seasonal variation of macrobenthic diversity indices}

The spatial and seasonal variations of Shannon-Wiener diversity index $(\mathrm{H})$, Simpson index of diversity (D), species 

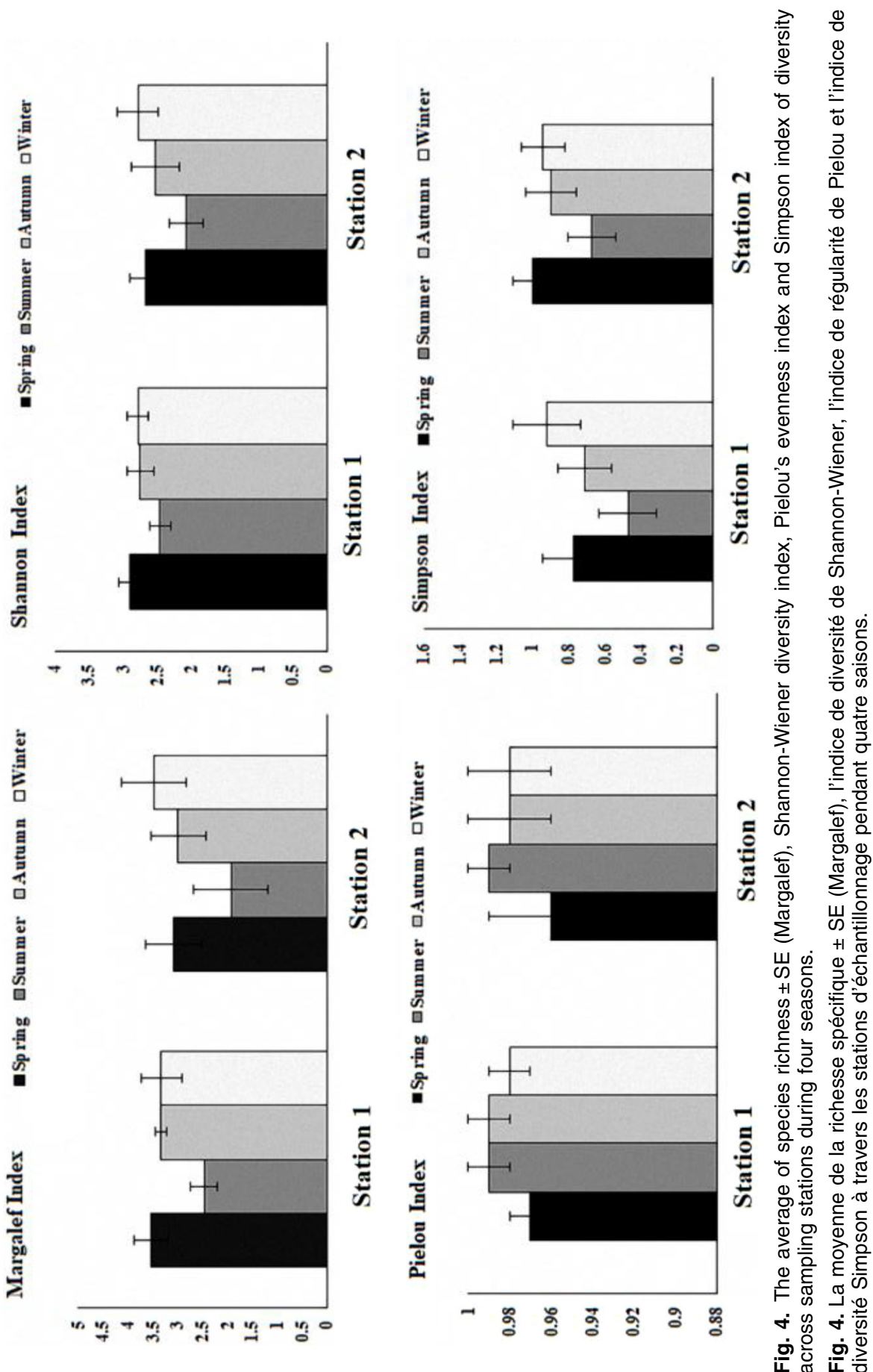

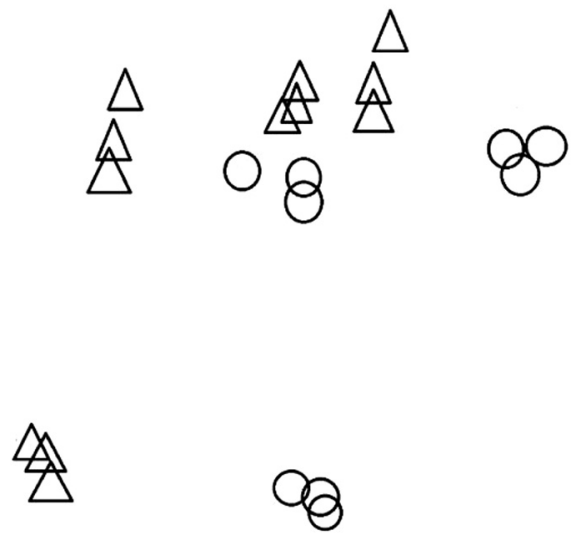

$\triangle \triangle^{s 1}$

Fig. 5. The comparison of macrobenthic assemblage structure using the non-parametric multidimensional scaling (NMDS).

Fig. 5. La comparaison de la structure d'assemblage macrobenthique en utilisant la mise à l'échelle multidimensionnelle non paramétrique (NMDS).

richness (Margalef: M) and Pielou's evenness index $(\mathrm{J})$ are displayed on Figure 4. The species richness (Margalef Index) showed a significant difference among the four seasons (2way ANOVAs; $F=4.31 ; P<0.05)$ and seasonal differences depended on studied station (2-way ANOVAs; $F=5.83 ; \quad P<0.01)$. There was no significant difference for the three other indices between stations $(P>0.05)$ and among four seasons $(P>0.05)$.

The comparison of the community structure of macrobenthos between the two stations using the NMDS indicated a partial overlap between the communities collected in the two stations (Fig. 5). ANOSIM indicated a significant difference in the structure of the communities between the two stations (ANOSIM, $\mathrm{P}<0.05$ ). SIMPER analysis showed that most of the similarity in the community structure among samples at each station was mainly due Solen dactylus, Hediste diversicolor, CirratuIus cirratus and Sigalion edwardsi (Tab. 4). The comparison of the similarity index (Mean \pm SE) between the two stations showed that the similarity index was $79.5 \pm 11.5 \%$ in general, and the highest value was observed in winter (88.24\%) (Tab. 4).

A first PCA analysis based on physico-chemical parameters showed that salinity, dissolved oxygen, turbidity, nitrite, phosphate, and silicate were the most significant factors on the factorial axis 1 which explained $62.07 \%$ of the total variance while $\mathrm{pH}$ and nitrate were the most significant factors on factorial axis 2 which explained $24.56 \%$ of the total variance (Fig. 6). The densities of the most abundant species were strongly correlated with the axis 2 . The second PCA analysis included sediment parameters 


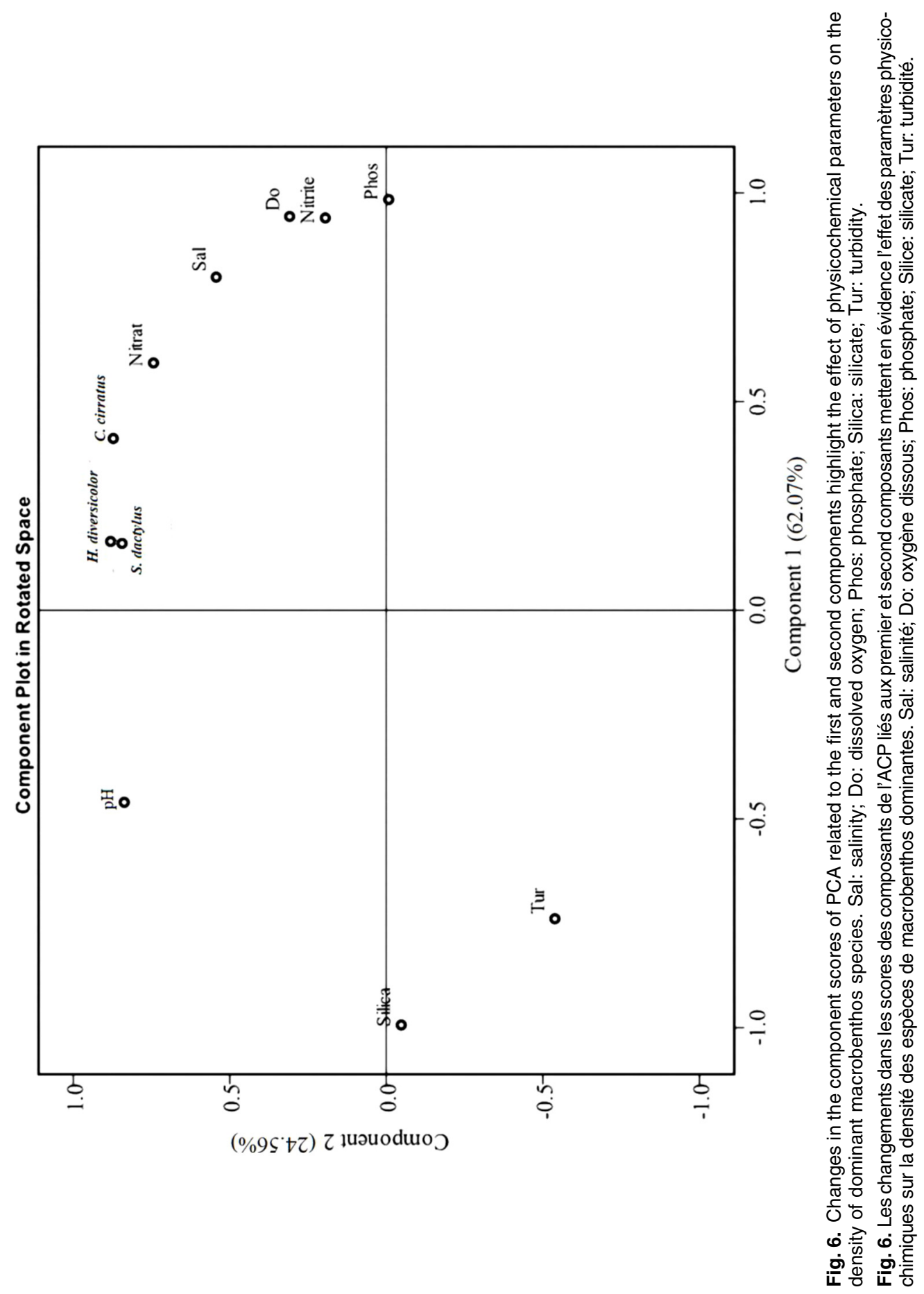




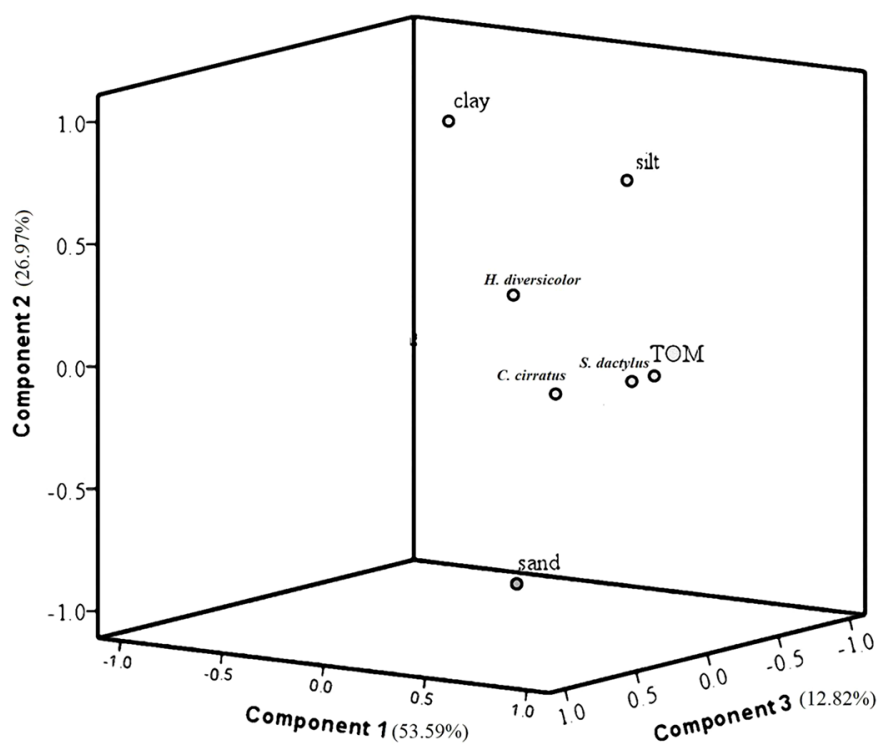

Fig. 7. Changes in the component scores of PCA related to the first, second, and third components to highlight the effect of sedimentary parameters on the density of dominant macrobenthos species.

Fig. 7. Changements dans les scores des composants de l'ACP liés aux premier, deuxième et troisième composants pour mettre en évidence l'effet des paramètres sédimentaires sur la densité des espèces de macrobenthos dominantes.

and the density of the dominant species showed that the TOM was the most significant factor on the density of Cirratulus cirratus, and Solen dactylus with the proportions of variance explained by the first three factorial components of 53.59, 26.97 and $12.82 \%$ respectively (Fig. 7 ).

\section{Discussion}

In this study, we have highlighted that the two habitats studied consisted of 20 species, mainly polychaetes, belonging to 14 families. An inventory of the macrobenthic fauna from the coast of the Arabian Sea reported 165 species belonging to 32 families with the dominance of polychaetes
(Joydes \& Damodaran, 2008). Our finding showed lower richness and abundance in comparison with the Arabian Sea study (Joydes \& Damodaran, 2008), which could probably be due to lower sampling effort and locations as well as lower ecological quality because of heavy-metal concentration (Taherizadeh \& Sharifinia, 2015).

The dominance of species such as C. cirratus may be due to its reproductive traits (e.g. continuous spawning and potential for asexual reproduction) (Petersen, 1999). On the other hand, it was also reported that the increasing of abundance in species such as $H$. diversicolor is probably related to small patches of dead seaweed at the sediment surface (Bolam et al., 2000). 
The small scale heterogeneity reported in the measured environmental parameters was already observed in tropical soft-sediment habitats around coral reefs from the Indian Ocean (Alsaffar et al., 2019). The environmental dissimilarity associated with seafloor high heterogeneity generates high differences in species distribution and promotes species composition and abundance even at relatively small spatial scales of tropical regions (Loiseau et al., 2017).

The total macrobenthic abundance recorded in the present study was quite low, ranging from zero to $12.5 \pm 0.58 \mathrm{ind} . / \mathrm{m}^{2}$ depending on the seasons. While higher abundance of benthic macrofauna are commonly reported in coastal areas in temperate regions (see Dolbeth et al., 2007) and sometimes in tropical latitudes (Alsaffar et al., 2019), Mackie et al. (2005) reported low abundance of molluscs and polychaetes in the Indian Ocean. The oligotrophy, low level of organic matter, and high temperature were reported as the main reasons for the low abundance of macrobenthic communities of tropical areas such as the Red Sea (Alsaffar et al., 2019).

The results of this study indicated a seasonal cycle in abundance with the highest and the lowest values reported in spring and summer, respectively for two dominant species. The increasing of temperature can be one of the reasons for the decreasing of the abundance of macrobenthos in summer. It was reported that the reducing of spawning and the increasing of energy consumption in the metabolic process can be related to environmental stress including temperature, dissolved oxygen concentration, and nutrient concentrations
(Karakassis \& Eleftheriou, 1997). Our results showed that the water temperature was the most significant factor in the abundance of macrobenthos where the lowest total abundances of dominant species and species richness were observed in summer with the average temperature above $30^{\circ} \mathrm{C}$. In parallel, the biotic interactions are commonly considered as more important factors determining abundance patterns than environmental factors at small scales (Jungerstam et al., 2014).

Shannon-Wiener diversity index, which is the most commonly used diversity index in ecological studies varied between 2.07 to 2.89 during summer and spring respectively, indicating a moderate diversity in both stations ( $\geq 5$, high diversity). According to Taherizadeh \& Sharifinia (2015), Margalef and Shannon-Wiener indices are able to detect ecological situations of stations through time. They reported high ecological status of stations at value between 4.12 and 4.15 of Margalef index and 2.09 and 2.18 of Shannon-Wiener index in the assessment of benthic community structure from subtropical estuaries of the Iranian coastal waters (Taherizadeh \& Sharifinia, 2015). No significant difference in diversity was reported between the two stations. The diversity index followed the same pattern of seasonal variation as the organic matter content with a maximum and a minimum during spring and summer respectively. The organic matter content has generally a strong impact on the local environment characteristics and the structure of benthic communities (Tomassetti et al., 2016). Evenness values of our study (0.98) indicated no dominance 
patterns in the soft-bottom sediments around coral habitats as already mentioned by Alsaffar et al. (2019) from the open water of the Red Sea. The lack of dominance can be related to low densities of all species in sandy sediment (Alsaffar et al., 2019). These results are in agreement with previous observations in Kuwait's waters, Persian Gulf that showed meaningless dominance, high diversity and low density of species (Al-Yamani et al., 2009). The highest and lowest Margalef species richness index was observed during spring and summer respectively. Moreover, station 1 showed higher species richness than station 2. The favorable environmental conditions of spring including lower temperature and higher organic matter can explain higher species richness during this season.

The PCA analyses indicated that the most significant factors influencing macrobenthic abundance were phosphate, dissolved oxygen, and TOM. A close relationship between environmental factors and the characteristics of benthic communities was observed in many studies (Anderson et al., 2004; Veiga et al., 2016). The main factors include sediment grain size, salinity, currents and pollutants as controlling factors of community structure of macrobenthos in tropical and subtropical regions, including the Persian Gulf (Gomes Veloso et al., 2003).

In this study, the summer and autumn seasons were characterized by the lowest level of dissolved oxygen. The increasing temperature can induce the decreasing concentration of the dissolved oxygen of coastal waters during the summer season with a direct effect on macrobenthic density (Seitz et al., 2009). The decrease in the density of macrobenthos during summer could be then related to the decrease of dissolved oxygen and the increase of temperature. The hypoxia can reduce the overall availability of secondary production to higher trophic levels and affect overall productivity (Seitz et al., 2009). The results of the PCA indicated also a negative effect of turbidity on total abundance of macrobenthos that could be explained by the fact that the maximum turbidity and minimum total abundance were observed during the summer season at both stations. Turbidity has been already reported to alter the structure of communities, and the density and reproduction of organisms in marine environments (Henley, 2000).

In terms of sediment properties, the PCA analysis showed that the TOM was the most significant factor controlling the densities of the dominant species including $C$. cirratus and $S$. dactylus as reported in previous studies (Thilagavathi et al., 2013; Veiga et al., 2017). The organic matter content can increase the growth of macrofauna through the supplying of food sources (Schelske \& Odum, 1962). Subsequently, the abundance of benthic organisms is highly dependent on organic carbon (Thilagavathi et al., 2013) even if organic matter was rarely known as a limiting factor of seasonal abundance of macrobenthos (Qasim et al., 1974). Marine sediments enriched with organic matter may produce hydrogen sulfide resulting in the reduction of oxygen with deleterious effects on macrofauna (Dittmann, 2012). On the other hand, there is an 
inverse relationship between the size of sediment particles and the amount of organic matter in the sediment (Veiga et al., 2017).

The range of sediment grain size tolerated by each species can reflect the relationship between sediment and macrobenthos (Hily et al., 2008) and the lifestyle of macrobenthic species can be determined by sediment features in their environment (Pinedo et al., 2000). Furthermore, the significance of sediment characteristics could become higher at smaller spatial scales (Schückel et al., 2015). In our study, the percentage of sediment particles at the two stations was relatively similar with a higher percentage of sandy grains and low organic matter and do not contribute to discriminate the community structure and composition described at both stations.

The salinity and sediment grain size were reported as the most significant factors on the communities of macrobenthos in the Persian Gulf (Coles \& McCain, 1990). Koampf \& Sadrinasab (2006) reported minimum and maximum salinity of the Persian Gulf during spring and autumn, respectively in agreement with our observations. Moreover, the results of our study confirm the salinity as one of the most important factors influencing the communities of macrobenthos in addition with temperature.

\section{Conclusion}

Our results have the potential for providing baseline date to design the monitoring programs for the detection of anthropogenic perturbations on coastal habitats. In general, the results reflected low density of coral macrobenthic communities in Larak Island. The present study was one of the first evaluating the influence of environmental conditions on macrofauna in soft bottoms around coral reefs of Larak Island from Persian Gulf, a very poorly studied area on earth.

\section{Funding}

No funding was received for this investigation

\section{Conflict of interest}

The authors declare that they have no conflict of interest.

\section{Ethical approval}

All applicable international, national, and/or institutional guidelines for the care and use of animals were followed by the authors

\section{Sampling and field studies}

All necessary permits for sampling and observational field studies have been obtained by the authors from the competent authorities

\section{Data availability}

The datasets generated during and/ or analysed during the current study are available from the corresponding author on reasonable request. 


\section{Author contribution}

ST original hypothesis, data collection. SS data preparation, statistical analysis, writing the paper. EK contributing in original hypothesis, advice in the methods. MSM guidance in the methods and results. SB helping for the fieldworks and data collection.

\section{REFERENCES}

Alsaffar Z., Cúrdia1 J., Borja A., Irigoien X. \& Carvalho S., 2019. Consistent variability in beta-diversity patterns contrasts with changes in alpha-diversity along an onshore to offshore environmental gradient: the case of Red Sea soft-bottom macrobenthos. Marine Biodiversity 49: 247-262.

Al-Yamani F., Boltachova N., Revkov N., Makarov M., Grintsov V., Kolesnikova E. \& Murina G.V., 2009. Winter species composition, diversity and abundance of macrozoobenthos in Kuwait's waters, Arabian Gulf. ZooKeys 31: 178-38.

Anderson M.J., Ford R.B., Feary D.A. \& Honeywill C., 2004. Quantitative measures of sedimentation in an estuarine system and its relationship with intertidal soft sediment infauna. Marine Ecology Progress Series 272: 338-48.

APHA, 2002. Standard methods for the examination of water and wastewater, 19 ed. Washington, DC: American Public Health Association.

Bolam S.G., Fernandez T.F., Read P. \& Raffaelli D., 2000. Effects of macroalgal mats on intertidal sandflats: an experimental study. Journal of Experimental Marine Biology and Ecology 249: 123-137.
Caeiro S., Costa M., Ramos T., Fernandes F., Silveira N., Coimbra A., Medeiros G. \& Painho M., 2005. Assessing heavy metal contamination in Sado Estuary sediment: an index analysis approach. Ecological Indicators 5: 151-169.

Casas Guell E., Teixidó N., Garrabou J. \& Cebrian E., 2015. Structure and biodiversity of coralligenous assemblages over broad spatial and temporal scales. Marine Biology 162: 901-912.

Castelli C., Lardicci D. \& Tagliapietra D., 2004. Soft-bottom macrobenthos. Biologia Marina Meditteranea 11: 99-131.

Coles S.L. \& McCain J.C., 1990. Environmental factors affecting benthic infaunal communities of the western Arabian Gulf. Marine Environmental Research 29: 2898-315.

Dittmann S., 2012. The Wadden Sea ecosystem: stability properties and mechanisms. Berlin: Springer, $307 \mathrm{p}$.

Dolbeth M., Ferreira O., Teixeira H., Marques J.C., Dias J.A. \& Pardal M.A., 2007. Beach morphodynamic impact on a macrobenthic community along a subtidal depth gradient. Marine Ecology Progress Series 352: 113-124.

Fukunaga A., Kosaki R.K. \& WagnerD., 2017. Changes in mesophotic reef fish assemblages along depth and geographical gradients in the Northwestern Hawaiian Islands. Coral Reefs 36: 785-790.

Gomes Veloso V., Soares Caetano C.H. \& Silva Cardoso R., 2003. Composition, structure and zonation of intertidal macrofauna in relation to physical factors in microtidal sandy beaches at Rio de Janeiro State, Brazil. Scientia Marina 67: 3938-402.

Henley W.E., Patterson M.A., Neves R.J. \& Dennis Lemly A., 2000. Effects of sedimentation and turbidity on lotic food 
webs: a concise review for natural resource managers. Reviews in Fisheries Science 8: 125-139.

Hily C., Le Loc'h F., Grall J. \& Glémarec M., 2008. Soft bottom macrobenthic communities of North Biscay revisited: longterm evolution under fisheries climate forcing. Estuarine, Coastal and Shelf Science 78: 413-425.

Jackson J.B.C., 2010. The future of the oceans past. Philosophical Transactions of the Royal Society B: Biological Sciences 365: 3765-3778.

Jungerstam J., Erlandsson J., McQuaid C. D., Porri F., Westerbom M. \& Kraufvelin P., 2014. Is habitat amount important for biodiversity in rocky shore systems? A study of South African mussel assemblages. Marine Biology 161: 1507-1519.

Kahng S.E., Copus J.M. \& Wagner D., 2014. Recent advances in the ecology of mesophotic coral ecosystems (MCEs). Current Opinion in Environmental Sustainability 7: 72-81.

Karakassis I. \& Eleftheriou A., 1997. The continental shelf of Crete: structure of macrobenthic communities. Marine Ecology Progress Series 160: 185-196.

Koampf J. \& Sadrinasab M., 2006. The circulation of the Persian Gulf: a numerical study. Ocean Science, European Geosciences Union (EGU) 2: 27-41.

Lindfield S.J., Harvey E.S., Halford A.R. \& Mcllwain J.L., 2016. Mesophotic depths as refuge areas for fishery-targeted species on coral reefs. Coral Reefs 35: 125-137.

Loiseau N., Legras G., Kulbicki M., Mérigot B., Harmelin-Vivien M., Mazouni N., Galzin R. \& Gaertner J.C., 2017. Multicomponent $\beta$-diversity approach reveals conservation dilemma between species and functions of coral reef fishes. Journal of Biogeography 44: 537-547.
Mackie A.S., Oliver P.G., Darbyshire T. \& Mortimer K., 2005. Shallow marine benthic invertebrates of the Seychelles Plateau: high diversity in a tropical oligotrophic environment. Philosophical Transactions of the Royal Society A: Mathematical, Physical and engineering sciences 363: 203-228.

Moradi M., Malekzadeh-Viayeh R. \& Eshaghi-Rad J., 2014. Biodiversity of scleractinian corals in the reefs of Qeshm and Larak Islands of the Persian Gulf, in association with environmental variables. Journal of the Marine Biological Association of the United Kingdom 94: 907-916.

Ostrovskii A. \& Zatsepin A., 2011. Shortterm hydrophysical and biological variability over the northeastern Black Sea continental slope as inferred from multiparametric tethered profiler. Ocean Dynamics 61: 797-806.

Petersen M.E., 1999. Reproduction and development in Cirratulidae (Annelida: Polychaeta). Hydrobiologia 402: 107-128.

Pinedo S., Sardá R., Rey C. \& Bhaud C., 2000. Effect of sediment particle size on recruitment of Owenia fusiformis in the Bay of Blanes (NW Mediterranean Sea): an experimental approach to explain field distribution. Marine Ecology Progress Series 203: 205-213.

Pyle R.L., Boland R., Bolick H., Bowen B. W., Bradley C.J., Kane C., Kosaki R.K., Langston R., Longenecker K., Montgomery A., Parrish F.A., Popp B.N., Rooney J., Smith C.M., Wagner D. \& Spalding H.L., 2016. A comprehensive investigation of mesophotic coral ecosystems in the Hawaiian Archipelago. PeerJ 4: e2475.

Qasim S.Z., 1974. Some problems related to the food chain in a tropical estuary. In: Marine food chains (J.H. Steele, Ed.), pp. 45-51. Los Angeles, USA: University of California Press. 
Schelske C.L. \& Odum E.P., 1962. Mechanisms maintaining high productivity in Georgia estuaries. Proceedings of the Gulf and Caribbean Fisheries Institute 14: 75-80.

Schückel U., Beck M. \& Kröncke I., 2015. Macrofauna communities of tidal channels in Jade Bay (German Wadden Sea): spatial patterns, relationships with environmental characteristics, and comparative aspects. Marine Biodiversity 45: 841-855.

Seitz R.D., Dauer D.M., Llansó R.J. \& Christopher W., 2009. Long broadscale effects of hypoxia on benthic community structure in Chesapeake Bay, USA. Journal of Experimental Marine Biology and Ecology 381: 4-12.

Taherizadeh M.R. \& Sharifinia M., 2015. Applicability of ecological benthic health evaluation tools to three subtropical estuaries (Azini, Jask and Khalasi) from the Iranian coastal waters. Environmental Earth Sciences 74: 3485-3499.

Tagliapietra D. \& Sigovini M., 2010. Benthic fauna: collection and identification of macrobenthic invertebrates. Terre et Environnement 88: 253-261.

Thilagavathi B., Varadharajan D., Babu A., Manoharan J. \& Vijayalakshmi S., 2013. Distribution and diversity of macrobenthos in different mangrove ecosystems of Tamil Nadu Coast, India. Aquaculture Research and Development 4: 199206.

Tomassetti P., Gennaro P., Lattanzi L., Mercatali I., Persia E., Vani D. \& Porrello S., 2016. Benthic community response to sediment organic enrichment by Mediterranean fish farms: case studies. Aquaculture 450: 262-272.

Veiga P., Torres A.C., Aneiros F., SousaPinto I., Troncoso J.S. \& Rubal M., 2016. Consistent patterns of variation in macrobenthic assemblages and environmental variables over multiple spatial scales using taxonomic and functional approaches. Marine Environment Research 120: 191-201.

Veiga P., Redondo W., Sousa-Pinto I. \& Rubal M., 2017. Relationship between structure of macrobenthic assemblages and environmental variables in shallow sublittoral soft bottoms. Marine Environment Research 129: 396-407.

Zhou F., Liu Y. \& Guo H., 2006. Application of multivariate statistical methods to water quality assessment of the watercourses in Northwestern New Territories, Hong Kong. Environmental Monitoring and Assessment 132: 1-13. 